\title{
UNPRODUCTIVE EXPENDITURE AND SPECTACULAR MERCHANDISE
}

\author{
Vincenzo Susca \\ Lersem - Laboratoire d'études et de recherches en Sociologie et en Ethnologie de Montpellier, Insti- \\ tut de Recherche en Sociologie et Anthropologie, Université Paul-Valéry Montpellier, France
}

\begin{abstract}
In order to fully grasp the spirit of our times, we need to analyse fully the contemporary relationship between spectacle and consumption: spectacular consumption and the spectacle of consumption. The chain of sign merchandise (Baudrillard, 1968) is simultaneously a mean and a vehicle of adherence to the productive and political system. It takes on extraordinary value from the moment it welcomes all that is non-rational in a rationalised society, as well as it embodies the anti-utilitarian aspect of a social system based solely on the logic of utilitarianism. In this sense, the cycle of spectacular consumption coincides with the consumption of bourgeois individuality, while the mass that has become public becomes the matrix in which the subject loses itself and cushions the weight of change in a way to express the impulses marginalized by the social system.
\end{abstract}

KEYwORDS

spectacle; imaginary; consumption

\section{A DESPESA IMPRODUTIVA E A MERCADORIA ESPETACULAR}

\begin{abstract}
Resumo
Para apreender corretamente o espírito de nosso tempo, é necessário analisar em profundidade e na superfície a correspondência contemporânea entre o espetáculo e o consumo: consumo espetacular e espetáculo de consumo. A cadeia das mercadorias-signos (Baudrillard, 1968), meio e veículo de adesão ao sistema produtivo e político, assume um valor extraordinário a partir do momento em que acolhe tudo o que é não-racional numa sociedade racionalizada, bem como o aspeto anti-utilitarista de um social focado, precisamente, na lógica do utilitarismo. Nesse sentido, o ciclo dos consumos espetaculares coincide com o consumo da individualidade burguesa, enquanto a massa que se tornou público se torna a matriz na qual o sujeito se perde para amortecer o peso das mudanças e exprimir as pulsões marginalizadas pelo sistema social.
\end{abstract}

\section{Palavras-chave}

espetáculo; imaginário; consumo 


\section{SPECTACULAR COMMODITY}

The spectacle presents itself for the city-dweller as a distraction from the alienation to which he is compelled in order to produce goods; however, it is only from the moment that he is linked to productive activity and its demands that he can achieve a perfect connection between labor and time of leisure, the latter becoming the vital lymph of the former. When such a network of reciprocal links is established, all spectacle is commodified and all merchandise becomes spectacularized. The use or exchange value of the object loses its centrality to become the prerogative of its symbolic value and, precisely, by virtue of the possibility of staging, through different tools or screens, the nature of the social body, its relationships, its dreams and even its hallucinations. This is why cinema represents the fundamental moment in which confusion between merchandise and spectacle becomes realized, the former becoming the object of the latter, and vice versa, but above all, both functioning as containers of a social content: the public.

The history of cultural industry is thus superimposed on history from the moment that the social body finds in the binomial consumption-spectacle the axis that orients social togetherness, beyond the imperatives of established order. The whirlwinds of communication inaugurated by the phantasmagoria of spectacular commodity encourage, on the one hand, the city-dweller to distract himself from his alienated condition to which he is nevertheless forced by social constraint. On the other hand, theses impulses comfort the lowest bodily (Bakhtine, 1965/1998), spirits of the masses, weaving new networks of horizontal solidarity between social groups and relativizing the values in which the system finds its core, first of all undermining the principle of utility.

We think possible, at least in principle, to make the dimension of spectacle as well as the consumption it promotes, functional within productive order and its economic, political and moral demands. Better still, this field must remain in constant reference to the value of work and its imperatives, remaining a kind of parenthesis always refering to Prometheus. All social energy must be directed and projected towards this goal. As we have seen, it is for this reason that cinema presents itself as an "art of the factory" (Abruzzese, 1973/2001). According to the same logic, the public of the cultural industry is foreshadowed within the scenario of great Universal Exhibitions, where masses were called upon to gaze with wonder and admiration upon the prodigies of technology, and therefore produced by their alienated labor.

This basis nourishes fetishism of commodity, ultimately addressed, in many ways, to the body of its producer, to the one who it stems from. We thus end up more or less directly adoring our own activity. In this sense, social networks - through which we end up worshipping what we are - are merely the culmination of a long process aimed at making the user the true fetish of its social environment. This narrative represents a contradictory element, dangerous for the order that generates it. It is true that the chain of commodification strengthens the industry that presides it. Its phantasmagorias, especially from the moment they are linked to dreamlike devices of spectacle, trigger at the same time desires and needs in which the happiness of the social body tends to transcend the 
limits of the factory. They project themselves into imaginary worlds where every object is no longer a reference to its market value but to sheer emotion, to the body that internalizes it and makes it its own self. The very origin of its depassement is however inscribed in the cultural industry and in consumer society. In spite of this element, those who are concerned with promoting the political-productive structure tune in ardently on the productivist myth, censoring the dissolute pleasures to which the spectacular drifts give access. So much so that

any general judgement on social activity implies the principle that any special effort must be reducible, in order to be valid, to the basic necessities of production and conservation. Pleasure, whether it consists of art, accepted debauchery or play, is reduced in the intellectual representations that are in force to a concession, that is to say, to a neglection whose role would be end up being subsidiary. The most appreciable part of life is given as the condition - sometimes even as the regrettable condition - of productive social activity. (Bataille, 1949/2003, p. 26)

In fact labor and reason must be the foundations of a togetherness inscribed within the framework of an abstract project based on production and sacrifice. It has its projection into future and its identity substratum rooted in ideology. The chain of produced objects serves to establish relations between "individuals" in a continuous reference to principles that transcend them: the social contract, the political-productive order of nations, perfect society... This way reveals the potentiality of the social to become a single body and to discover itself as a common entity. On the other hand the impulses that inhabit it and constitute its deep imagination, are suppressed and always kept at bay. The achievement of modernity thus inaugurates, as a great novelty of History, a rationalized, utilitarian way of relating to objects and people, projected towards a higher goal than that of just "inhabiting" the social body.

In the economies and law systems that preceded ours, there is hardly ever a simple exchange of goods, wealth and products in the course of a deal between individuals. First of all, they are not individuals but communities that oblige each other, exchange and contract. (...) Moreover, what they exchange is not exclusively goods and wealth (...). It is above all politeness, feasts, rituals, military services, women, children, dances, festivals, fairs, the market for which is only one of the terms of a much more general and permanent contract. (Mauss, 1934/2004, pp. 150-151)

The exchange of goods, in Western context, becomes the means and the end, generating a machine capable of separating individuals, reuniting them only when they serve to perpetuate the utilitarian structure. Dances, shows, fairs, all the institutions which, in pre-modern times, reinforced the togetherness of the social body (Durkheim, $1912 / 2005)$, are now relativized and bent to the service of the triumphal march of reason 
and progress. All the discourses deployed by the political system tend to name, and thus to construct, a social reality that conforms to a criterion of balance and usefulness, and disregards any waste, non-activity or excesses that may harm political-productive institutions. They oppose the instincts that have always constituted the way in which the social body has melted, through trance, celebration or waste, giving life to this coming and going between oneself and the other (the divine, nature, the foreigner).

The core of modern culture dominates these basic instincts and bases its own morality on this domination, through the exercise of its power-knowledge, constructs discourses stigmatizing any unproductive waste. On the other hand

it is true that personal experience, if it comes from a juvenile man, capable of wasting and destroying without reason, belies this wretched conception every time. But even as he lavishes and destroys himself without taking the slightest account of it, the most lucid person ignores why, or imagines himself sick; he is incapable of justifying his conduct in a utilitarian way, and the idea does not come to him that a human society can have, like him, an interest in considerable losses, in catastrophes that provoke, in accordance with defined needs, tumultuous depressions, anxiety attacks and, in the final analysis, a certain orgiastic state. (Bataille, 1949/2003, p. 26)

The cultural industry serves to link the impulses of the masses that go beyond bourgeois order to its productive and moral system, allowing society to live potentially unbridled passions with restraint, even contentment; it might even simulate an expenditure that is impossible to experience concretely because it is endowed with a destructive soul regarding the texts and contexts of modern life.

It is likely that the Party has encouraged prostitution as a safety valve for instincts that cannot be completely suppressed. A little debauchery meant little, as long as it was practiced in secret and without joy. (Orwell, 2008, p. 70)

\section{THE CROWD BECOMING MEDIA}

The accumulation of masses in the metropolis, the intensification of communication flows - especially in the nocturnal dimension and outside of labor - have unleashed practices that tend to nuance categorical imperatives. They disarticulate the utilitarian system, and along that, the backbone of political order. Each time these gatherings take place, imagination is filled with figures who constantly allude to waste, dissolution, death, or any act that carries within itself the sabotage of the system. This is how metropolitan legends proliferate, weaving the praise of great delinquents and prostitutes, increasing the fascination and fear of the stranger and the desire to get out of oneself and lose oneself in something greater than oneself. 
Metropolitan lifestyle, as well as its extension into the territories of collective imaginary, generates urban and electronic effervescence that makes the masses vibrate, covering the instituted morals and their economies with emotions. When the cultural industry takes up the challenge of crystallizing the agents of the nocturnal imaginary, the individual who, according to Bataille (1949/2003), was not capable of imagining an order other than utilitarian and rationalist, begins to discover all the potentialities immanent to his being there, in the mass. The phantasmagoria of the spectacular commodity thus succeeds in supporting the dreams of the individual, projecting him beyond his identitarian cage, in which he is locked in. On the other hand, it confers a new splendour, another life, beyond economy, on the chain of industrial objects. It was necessary to endow the objects produced by the factory with an aura capable of welcoming the body of the masses, of activating with it a game of exchanges, of amorous excitement and nostalgia.

Only the dimension of spectacle will make this conjunction possible. The crowd thus becomes the medium (Rafele, 2010) to which all objects and images must refer. They have the mission of conveying a symbolic order that is more complete and dense than the one actualized in factories, where the individual prevails over the mass. It is this delicate passage that allows the individual to access another subjectivity, from which the pivot of sociopolitical structure sees its bases modified. When the stroller, or the blasé, enters the mass and enjoys its emotional fullness (Benjamin, 1989/2006), the whole order of Leviathan is relativized (Marramao, 2000) by the subjectivity that should submit in an orderly manner to its own representation. The individual is no longer isolated, the social contract that binds him to others only insofar as they project themselves together into the transcendence of the sovereign body, substituted by an affective contagion that prevails over everything and globality.

The stroller is still on the threshold, both of the big city and the bourgeoisie. Both have not yet won him over; he does not feel at ease with either; and he seeks refuge in the crowd. (...) The crowd is the veil through which the well-known city appears to the stroller as a phantasmagoria. In this phantasmagoria, it is sometimes landscape, sometimes space. (Benjamin, 1955/2000, p. 155)

The cycle of spectacular consumptions coincides with the consumption of bourgeois individuality, while the mass that has become public becomes the matrix in which the subject loses himself to cushion the weight of change and express the impulses marginalized by the social system. If it is true that the spectacular commodity becomes the sublimation of commodity, we cannot ignore the corollary of such a radical shift: the displacement of matter that channels societal energy towards illusions unleashed by images and objects. This is opposed to reflection in the cathedral of the factory and of the town hall. When Debord (1988) insightfully writes that "the humanism of commodity takes charge of the 'pleasures and humanity' of the worker, simply because political economy can and must now dominate these spheres as political economy" (p. 71), he forgets to 
add that "the humanism of commodity" does not only follow the meaning of the social system. On the contrary, it becomes capable of agitating new initiatory pilgrimages on the part of the masses precisely because it gives them, albeit in the form of a simple illusion, the possibility of living an experience different from that of instituted social systems. It provides the desire of holidays, shivers of love and dreams that are irreducible to the productive and political goals that have been established. What society, moreover, is not shaken and stirred to the core by the proliferation of "illusions"?

Despite the most inflexible and systematic deployments of images and messages from above, no social paradigm, even totalitarian, has ever succeeded in imposing a privileged meaning on such hallucinations, enjoyments and symbolic drifts. Consumption and the spectacle thus serve the system only to the extent that they support its economic order, whereas, as far as the imaginary is concerned, they tend to constitute a subjectivity, an immaterial placenta, idiosyncratic in relation to instituted morality. Here, the mass and its fragmentation into tribes, networks or clouds prevails over the individual, the ethics of aesthetics over ideology, unproductive expenditure over controlled utilitarianism (Joron, 2009). On the other hand, homo œconomicus is as much a novelty of History as it is an ideal-typical subject, even before it is effective. According to Mauss, indeed,

it is our Western societies that have, very recently, made the human an "economic animal". But we are not yet all such beings. In our masses and in our elites, pure and irrational spending is common practice; it is still characteristic of the few fossils of our nobility. Homo œconomicus is not behind us, he is before us; as the man of morality and duty; as the man of science and reason. For a very long time, man has been something else; and not long ago he was a machine, moreover a calculating machine. We are fortunately still far from this constant and icy utility calculation. (Mauss, 1934/2004, p. 271)

The advent of the cultural industry coincided with the cracking, in the depths of collective life, of the adherence to the order of values of society based on the leitmotif of progress, utilitarianism and abstract reason. The debauchery that escapes from the darkest recesses of the metropolis merges with the massification of society and becomes, as it were, its incipit, its secret thread. Uncontrolled emotions, performances, hallucinations and phantasmagorias become the daily bread of the masses (Auclair, 1970), to the point of pushing social systems to attempt to manipulate them. It is interesting, moreover, to verify the different paths taken by the United States and by Europe: whereas, in the first case, the discourse of the commodity and the spectacle becomes the mediation and the motor of the relationship between public and established powers, in the second case, it is directly the political - in its totalitarian versions - that incorporates, in the most exacerbated way, the principle of spectacle and its emotionality.

While in the United States the discourse of the commodity becomes the link, albeit a precarious one, between mass and politics, in Italy, Germany and the former Soviet Union, politics contain the need for emotional crossing and imaginary bathing that the 
mass that has become a public feeling together. Like merchandise in America, politics in Europe are thus transformed into a fetish in which the monstrous nature of the mass is revealed. It is useless here to dwell on the reasons for this investment and on the effects it provokes, when it seems more relevant, in the framework of our discourse, to show how, in both cases, the emergence of the mass coincides with the tragic manifestation of sacrifices, consumptions and destruction of pre-existing structures. The humanism of the spectacular commodity will only emerge victorious because it is the most apt to correspond to the nature of the social body and its playful and festive imagination, to its indispensable fantasies, always betrayed by political regimes based on historical ideologies. Moreover, the spectacle of commodity and the commodity of the spectacle are closely linked, from a proxemics and emphatic point of view, to the space-time of daily life. They are absorbed by its belly while being similarly absorbed.

In the wake of the paradigm shift imposed by spectacular society from the second half of the twentieth century onwards, the principle of reality on which the social systems were based came up against and shaken, despite the intentions of its producers. The logic of spectacular consumption, based on the preponderance of the imaginary, illusions and unbridled enjoyment, manifests itself as ever less controllable within the framework of schemes that want to prescribe order to it. "The real consumer becomes a consumer of illusions. The commodity is that illusion which is actually real, and the spectacle is its general manifestation" (Debord, 1988, p. 72).

\section{DISTORTION AND CONVALESCENCE}

The spectacular dispositif intensifies the public's imaginative faculty and disseminates interpretations, dreams and experiences of reality that corrode the monolithic pedestal on which our civilization was built. The dissemination of images and distractions cannot be limited within the intentional framework of the producers, since, on the one hand, consumption is always socially situated and, on the other hand, the semantic basin in which the transfiguration of reality takes place is the dreaming body of the mass. Thus a process of weakening of the "being" takes place that dismantles identity and the processes of identification prefigured by the system to maintain itself and reveals all its limits, as well as their artificiality. Thus the fulfilment of the technological system - circulation and reproduction of objects, images and spectacles - carries within it the fulfilment and dissolution of metaphysics.

According to Martin Heidegger, the imposition of the world of modern technology, the Ge-stell, is not only the moment when metaphysics reaches its highest peak, but also, and for this very reason, "a first spark of the Ereignis" (Vattimo, 1987, p.180). This means that there is intrinsically something in the world of technique that escapes it, which is not simply "technical". It is only through a Verwindung of the Ge-stell that the possibility of an Ereignis (event, appropriation) is inaugurated. The first term refers to a tragic acceptance that is also in itself overcoming, distortion and convalescence. This is, according to 
Vattimo (1987), the essence of philosophical postmodernity: the dissolution of modernity, of its technique and metaphysics, thus coincides with the radicalization of the tendencies that have constituted it since its origin. From the moment when political-economic systems shift the challenge to the symbolic order of goods and spectacles, pushing the alliance of these elements to confirm their own order, they also lend themselves to their own distortion. This is because defending a collective imagination excited in the hand-tohand struggle of consumption and distraction becomes even more difficult.

In this field, the possibility of putting into discourse (Foucault, 1976) the most disturbing, destructive and voluptuous substances presents itself as a painful undertaking, although constantly repressed by the productive order and by scientific power. Societal action abandoned to the matrix of spectacular consumption is in itself the bearer of a chain of linguistic games, interpretations, distortions and creative destruction that undermines the foundations of social systems, substituting small mythologies, sacralisations of what is profane at the origin, a universe of meanings made up of tribal or local micro-narratives. All these factors lead to a reappropriation-distortion of technique, to a de-realisation of the real (Vattimo, 1987). This is how the "real world", the "story of an error", "ends up becoming a fable".

The true world, accessible to the wise, pious, virtuous man - he lives in it, he is that world.

The true world, inaccessible now, but promised to the wise, pious, virtuous man (to the "sinner who does penance").

The true world, inaccessible, which can neither be reached, nor proven, nor promised, but which, by the mere fact that it is thought, is consolation, commitment, imperative.

The true world - inaccessible? In any case, not yet reached. And, since not reached, unknown. It is therefore neither consolation, nor salvation, nor obligation: how can we be committed to something we do not know?

The "true world", an idea that no longer serves any purpose, that no longer even commits us to anything - a useless, superfluous idea, therefore a refuted idea: let us abolish it.

We have abolished the real world: what world was left? Perhaps the world of appearance? ... But no! Together with the real world, we have also abolished the world of appearances! (Nietzsche, 1889/2001, pp. 46-47) 
Interpreting the advent of the communication society and the logic of spectacular consumption that results from it, in the light of the convergence between the philosophies of Heidegger (quoted in Vattimo, 1987) and Friedrich Nietzsche (1889/2001), leads us to discover the flaws of modernity. As well we read, behind the disorder, the social reappropriations and the dark side raised by the collective imaginary, the elaboration of an order other than the one shaped by the long narrative of progress. Any illusion fomented by the spectacular devices generates a form of enchantment of the social body, a series of uncontrollable dreams, and yet always well founded on the nature of daily life and its most tragic and banal aspects. In this way, the ideology of happiness ceases to serve history and is incorporated into the practices of social subjects - in the being itself - in such a way as to push the individual to "let go of the being as a foundation" (Heidegger, quoted in Vattimo, 1987, p. 126).

The images and spectacles promoted by reality, and thrown into the viscera of consumption, into the heart of sociality, promote the actualization of several worlds beyond and below the social, each with a different meaning. In this sense, the advent of postmodernity, which has manifested itself completely with the sparks stirred up by the society of spectacle, can be read as the "death of God", or nihilism (Nietzsche, 1882/1998, p. 202). It would be a condition in which man explicitly recognizes the absence of foundation as constitutive of his reality. This means the crumbling of all universalism and the proliferation of fragments, splinters, micro-narratives, of everything that as chaotic as it is vital, disturbs the generalized asepsis into which the social has been reduced to a general rationalization of existence (Weber, 1904/1964).

We can argue that within the system itself lie the possibilities of its overcoming-distortion (verwindung), and thus that at the very moment when the modern order reaches its flourishing and apparently most glaring stage, that it paves the way for its decline. When ideology presents itself in the guise of the ideology of happiness, when the panoply of fetish objects produced by industry is dematerialized in spectacular phantasmagorias, the societal order is over-stimulated in its symbolic productions and creations. It is comforted in its being-together as pure sentient corporality, excited by an energy that goes beyond the rational order from which it stems.

Reality becomes unreal, fatally consumed through experimented games in the sovereign dimension of the imaginary. There each sense is reduced to a show, linked to the sensations of one or more bodies in love and re-enchanted. This is why the Ge-stell, in its amphibious nature, weapon of the Social. It is at the same time, an order in the hands of daily life, that carries in its maximum deployment, the accomplishment of the "all" and its sinking nature. The hybridization and reciprocal grafting that daily life achieves with the system of objects and, more generally, with the ecology of spectacle, cause the crumbling of the architecture on which the reality elaborated by modernity has been erected. The distinctions that served as a basis - object/subject, real/irreal, elite/masses - are melted and generate chaos at the heart of collective life. 
By losing these determinations, man and being enter an oscillating domain schwingend, which, in my opinion, must be imagined as the world of a "lighter" reality, made lighter because it is less clearly divided between truth and fiction, information and image: the world of the total mediatization of our experience in which we already find ourselves to a large extent. (Vattimo, 1987, p. 189)

In such a "lightened" reality, in which the content of real life is dematerialized in the flows of performances and communications, in the sparks stirred up by the societal aesthetics of Instagram, Tumblr or Snapchat, the resulting relativization of the political is superimposed on the emergence of an anomic sociality. All this mass previously separated into individuals separated by labor. Its irruption on stage, in one way or another, volens nolens, represents a continuous jamming of the official engine of History.

The logic of spectacular consumption, the matrix of collective experience from the second half of the 2oth century onwards, is driven by the convergence of iconophilia and neo-paganism, sensitivities of a polymorphous nature in the sense that they are based on the interpretative richness of the imagination. They are also based on the polysemy of the imagination and on the adoration of different objects, places, images, thus always undermining the foundations of all universalism and transcendence. The loss of self identity in the archetypical basin of unbridled consumption, the fusion with the other that takes place at the moment of sharing an ecstatic excitement for a product, a show or any element that refers to the relationship with the other, brings back to the stage the losses, excesses and unproductive expenditure that the human being cannot do without in order to counter the limits of the principle of reality in which he finds himself. As Bataille observed

human life, as distinct from legal existence and as it actually takes place on a globe isolated in celestial space, from day to night, from one country to another, human life can in no way be limited to the closed systems assigned to it in reasonable conceptions. The immense work of abandonment, flow and storm that constitutes it could be expressed by saying that it begins only with the deficit of these systems. At least it admits that order and reserve has meaning only from the moment when the ordered and reserved forces are freed and lost for purposes that cannot be subject to anything for which it is possible to be held accountable. It is only through such insubordination, however miserable, that the human species ceases to be isolated in the unconditional splendour of material things. (Bataille, 1949/2003, pp. 44-45)

Translation: Matthijs Gardenier 


\section{REFERENCES}

Abruzzese, A. (1973/2001). Forme estetiche e società di massa. Venice: Marsilio.

Auclair, G. (1970). Le mana quotidien. Structures et fonctions de la chronique de faits divers. Paris: Éditions Anthropos.

Baudrillard, J. (1968). Le système des objets. Paris: Gallimard.

Bakhtine, M. (1965/1998). L'œuvre de François Rabelais et la culture populaire au moyen-âge et sous la renaissance. Paris: Gallimard.

Bataille, G. (1949/2003). La part maudite. Précédé par la notion de dépense. Paris: Les Éditions de Minuit.

Benjamin, W. (1955/2000). Paris. La capitale del XIX secolo. In Angelus novus. Saggi e frammenti. Turin: Einaudi.

Benjamin, W. (1989/2006). Le livre des passages. Paris: Les Éditions du Cerf.

Debord, G. (1988). Commentaires sur la société du spectacle. Paris: Éditions Gérard Lebovici.

Durkheim, É. (1912/2005). Les formes élémentaires de la vie religieuse. Paris: PUF.

Foucault, M. (1976). Histoire de la sexualité. La volonté de savoir. Paris: Gallimard.

Joron, P. (2009). La vie improductive. Georges Bataille et l'hétérologie sociologique. Montpellier: PLUM.

Marramao, G. (2000). Dopo il leviatano. Individuo e comunità. Turin: Bollati Boringhieri.

Mauss, M. (1934/2004). Les techniques du corps. In M. Mauss (Ed.), Sociologie et Anthropologie. Paris: PUF.

Nietzsche, F.(1882/1998). Le gai savoir. Paris: Flammarion.

Nietzsche, F.(1889/2001). Crépuscule des idoles. Paris: Hatier.

Orwell, G. (1949/2013). 1984. New York: Penguin.

Rafele, A. (2010). La métropole. Benjamin et Simmel. Paris: CNRS Éditions.

Vattimo, G. (1987). La fin de la modernité. Nihilisme et herménetique dans la culture post-moderne. Paris: Éditions du Seuil.

Weber, M. (1904/1964). L'éthique protestante et l'esprit du capitalisme. Paris: Plon.

\section{BIOGRAPHICAL NOTE}

Vincenzo Susca is Associated Professor in Sociology at the Université Paul-Valéry in Montpellier. Member of the Lersem-Irsa laboratory, McLuhan fellow at the University of Toronto and editorial director of the Cahiers Europeens de l'imaginaire (CNRS Editions). $\mathrm{He}$ has published several books on the relationship between media, imaginary and daily life, including: Gioia tragica (Milano, 2009; Paris, 2010; Madrid, 2012); Les affinités connectives. Sociologie de la culture numérique (Paris, 2016; Porto Alegre, 2019) and Un oscuro riflettere. Black Mirror e l'aurora digitale (Milan, 2020; Montréal, 202O) with C. Attimonelli. 
ORCID: https://orcid.org/0000-0002-5489-6514

Email: vincenzo-susca@univ-montp3.fr

Address: 5 Place de la Comedie, Montpellier 34000, France

Submitted: $14 / 04 / 2020$

Accepted: 07/07/2020 